\title{
SEASONAL CHANGES IN THE OCCURRENCE OF OESTRUS FOLLOWING PROGESTERONE SUPPRESSION OF OVARIAN FUNCTION IN THE MERINO EWE
}

\author{
D. R. LAMOND \\ C.S.I.R.O., Division of Animal Physiology, Cunningham Laboratory, Mill Road, \\ St. Lucia, Brisbane, Queensland, Australia
}

(Received 18th December 1963)

Summary. Three groups of Merino ewes (a total of 150) kept in yards were studied for a period of 1 year. Vasectomized rams were with one group and occurrence of oestrus was noted. The presence and number of corpora lutea were observed by laparotomy at 6-week intervals. The annual rhythms in these characteristics were determined.

A second group of ewes received progesterone treatments at intervals of 6 weeks. Half the ewes were with vasectomized rams continuously but rams were with the others for only I week after the final progesterone injection. The period from the final injection to the onset of oestrus was determined. Introduction of rams increased the number of ewes showing oestrus at the beginning (late summer) and end (late winter) of the breeding season. The period to onset of oestrus was related to dose and frequency of progesterone injections, the time of the year, and introduction of rams. Periods to onset of oestrus became progressively longer after mid-winter (June) and a proportion of progesterone-treated ewes did not show oestrus in the 1 week period after cessation of progesterone injections in July, at a time when all untreated ewes were experiencing oestrous cycles. The implications of the seasonal change in the effects of progesterone on the ewes are discussed in relation to the sexual season.

A third group of ovariectomized ewes received progesterone followed by oestrogen, also at intervals of 6 weeks. The number of ewes showing oestrus during the period January to June was dependent on the dose of progesterone independently of the effect of dose of oestrogen. The relationship did not hold at other times. In general, there was considerable heterogeneity in mean responses and slopes of the dose-response lines.

\section{INTRODUCTION}

Administration of progesterone to Merino ewes during the breeding season suppresses ovarian function, and after cessation of treatment oestrus (and 
ovulation) may occur simultaneously in the ewes. Factors influencing the length of the period from the final injection of progesterone to the onset of oestrus include dose of progesterone and frequency of injections (Dutt \& Casida, 1948; Lamond \& Lambourne, 1961), time of day when final injection is given (Lamond \& Bindon, 1962), season of year (Lamond \& Bindon, 1962; Lamond, 1962a), presence of rams (Lamond, 1962b) and nutritive status (Lamond, 1963). It was decided to examine the effect of season in more detail and to compare the response with the normal annual rhythm of ovarian function. Seasonal changes in responsiveness to oestrogen in progesteroneprimed ovariectomized ewes have been reported (Raeside \& McDonald, 1959; Reardon \& Robinson, 1961). The possibility that this could have been due in part to an effect of progesterone prompted consideration of the incidence of oestrus in progesterone-primed ovariectomized ewes in the experimental design.

\section{Design}

\section{MATERIALS AND METHODS}

The experiment was conducted in three main parts.

A. A group that varied in size from forty-four to fifty-three ewes was kept with harnessed vasectomized rams for 1 year, and ewes showing oestrus were noted. At intervals of 6 weeks the ovaries of approximately half the ewes in the group were examined by laparotomy for corpora lutea. This group therefore provided information on the natural annual rhythm of oestrus and ovulation.

B. Two groups each of thirty-two ewes were given progesterone for periods of 2 weeks at intervals of 6 weeks, except for the fourth series which was 1 week late in starting. The date of the final injections each time was within a day or two of the date of laparotomy in Group A. There were eight ewes on each progesterone treatment in each series. The ewes were re-allocated at random to treatments for each series. One of the groups of thirty-two ewes (Group B1) had three vasectomized rams with it continuously. Vasectomized rams joined the ewes in the other group (Group B2) for a period of 1 week only, following cessation of hormone injections.

C. A group of twenty-eight ovariectomized ewes received progesterone treatments for 1 week and oestrogen 1 day after the final injection of progesterone. These treatments were conducted at 6 -week intervals and the time of the oestrogen injection coincided with the final injection of progesterone in Group B. There were seven ewes on each treatment. For each series of observations the twenty-eight ewes were re-allocated to the four groups at random.

The experiment was conducted over the period October 1961 to October 1962, with the exception of an additional series in November 1962 in Group C. It took place at the C.S.I.R.O. Pastoral Research Laboratory, Armidale, New South Wales. Armidale is situated at $30^{\circ} 3^{\prime} \mathrm{S}$ latitude and $151^{\circ}$ longitude. The mean maximum and minimum summer and winter temperatures $\left({ }^{\circ} \mathrm{F}\right)$ respectively are: 81.4 and 56.0 (January) and 53.6 and 32.4 (July). Rainfall averages $31 \mathrm{in}$./year of which $60 \%$ falls in the months October to March inclusive. 


\section{Hormone treatments}

There were nine series of observations (Tables 1, 2 and 3). In Series 1, 2, 3 and 9 the dosage levels of progesterone were: $2.5 \mathrm{mg} /$ day, $5 \mathrm{mg}$ every 2 days, 5 $\mathrm{mg} /$ day, and $10 \mathrm{mg}$ every 2 days. In the remaining series the dosage levels were: $5 \mathrm{mg} /$ day, $10 \mathrm{mg}$ every 2 days, $10 \mathrm{mg} /$ day, and $20 \mathrm{mg}$ every 2 days. The progesterone was dissolved in peanut oil and was given intramuscularly in the hind leg. The period of the injections was 15 days-i.e. fifteen daily injections or eight injections at intervals of 2 days. Injections were arranged so that the final one was given on a Monday. All injections were given 8.00 to 9.00 a.m. In Group C, $2.5 \mathrm{mg}$ or $10 \mathrm{mg}$ of progesterone were administered daily for 6 days. At midday on the 7th day $10 \mu \mathrm{g}$ or $40 \mu \mathrm{g}$ of stilboestrol in peanut oil were given subcutaneously. Progesterone and stilboestrol solutions were made up fresh each time from stock solutions, which in turn were replenished regularly.

\section{TABLE 1}

OESTRUS AND OVULATION IN GROUP A

\begin{tabular}{|c|c|c|c|c|c|c|c|c|}
\hline \multirow{2}{*}{ Series } & \multirow{2}{*}{ Date of laparotomy } & \multirow{2}{*}{$\begin{array}{c}\text { Total No. } \\
\text { ewes }\end{array}$} & \multicolumn{2}{|c|}{ Exves in oestrus* } & \multicolumn{4}{|c|}{ Ewes with corpora lutea $\dagger$} \\
\hline & & & No. & $\%$ & 0 & 1 & 2 & $\begin{array}{c}\% \text { cycling } \\
(1 \text { or } 2 \text { corpora })\end{array}$ \\
\hline $\begin{array}{l}1 \\
2 \\
3 \\
4 \\
5 \\
6 \\
7 \\
8 \\
9\end{array}$ & $\begin{array}{l}\text { 31st October } \\
\text { 13th December } \\
\text { 22nd January } \\
\text { 13th March } \\
\text { 16th April } \\
\text { 29th May } \\
\text { 12th July } \\
\text { 21st August } \\
\text { 2nd October }\end{array}$ & $\begin{array}{l}52 \\
47 \\
53 \\
47 \\
50 \\
44 \\
49 \\
51 \\
50\end{array}$ & $\begin{array}{r}7 \\
2 \\
7 \\
37 \\
39 \\
35 \\
41 \\
26 \\
3\end{array}$ & $\begin{array}{r}13 \\
4 \\
13 \\
79 \\
78 \\
79 \\
84 \\
51 \\
6\end{array}$ & $\begin{array}{r}9 \\
22 \\
13 \\
0 \\
0 \\
1 \\
0 \\
5 \\
27\end{array}$ & $\begin{array}{r}14 \\
1 \\
8 \\
20 \\
23 \\
21 \\
25 \\
18 \\
0\end{array}$ & $\begin{array}{l}2 \\
0 \\
1 \\
2 \\
1 \\
0 \\
0 \\
0 \\
0\end{array}$ & $\begin{array}{r}64 \\
4 \\
45 \\
100 \\
100 \\
95 \\
100 \\
80 \\
0\end{array}$ \\
\hline
\end{tabular}

* Ewes showing oestrus in the 18-day period prior to laparotomy.

$\dagger$ Ewes with recent ovulations or normal corpora lutea at the time of laparotomy.

\section{Animals}

Mature Merino ewes (fine-wool, aged 6 to 8 years) were used. So far as is known, all ewes had a satisfactory breeding history. In October 1961, when the experiment commenced, the ewes had been in yards for periods of 2 weeks to 6 months. During the period of the experiment, all ewes remained in yards and were fed a ration containing approximately $50 \%$ oat grain, $25 \%$ oaten hay and $25 \%$ lucerne hay. The ration was offered ad libitum in self-feeders. Body weights were taken at intervals of approximately 1 month and it was found that the average weights did not vary.

On occasions ewes were removed from the experiment and were replaced by ewes of similar age and history. There were no replacements in Group G. It was found in April 1962 that a ram brought into the experiment in February 1962 was not vasectomized and a number of ewes in Groups A and B had become pregnant. The records of these ewes were eliminated for the period they were pregnant. Some ewes in Group A, in which laparotomy was performed 


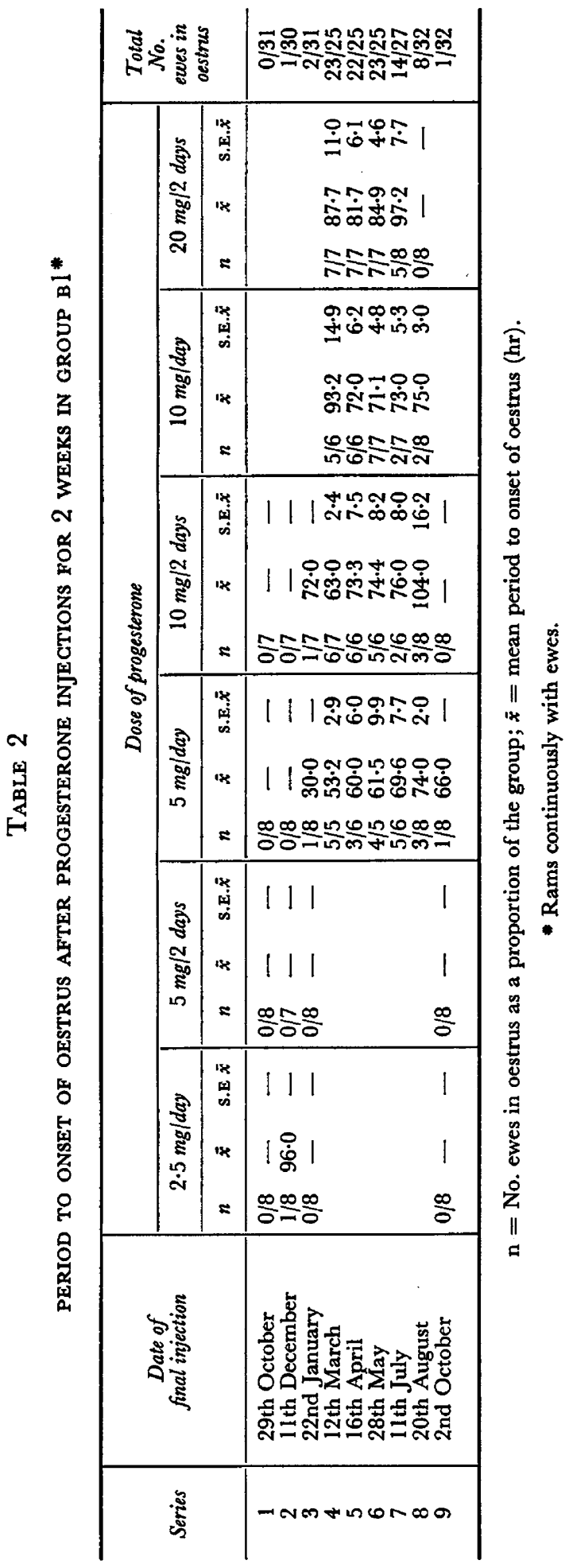


for ovarian examination, developed adhesions around the ovary. Ewes in which an ovary could not be properly examined were removed and their records up to the point that the adhesions developed were eliminated. About $5 \%$ of ewes died. Shearing was carried out in October each year. The ewes were given prophylactic drenches for control of intestinal parasites. The animals were treated for lice infestation in August 1962.

Twelve vasectomized Merino rams were used. When the rams were with ewes they wore marking harnesses (Radford, Watson \& Wood, 1960). Three rams were kept with Groups $A$ and $B 1$ and were replaced weekly. Two rams in Group $\mathrm{C}$ were also replaced weekly. Thus the rams were shifted regularly from group to group. There was no particular order of change nor were the same rams continuously kept together. The aim in handling the rams was to eliminate bias which might have been due to differences between rams either in detecting and marking ewes in oestrus or in 'teasing' ability.

Group B2 ewes were kept isolated in yards which had a path $6 \mathrm{ft}$ wide, or another yard, between it and any other group of ewes. Rams were placed with Group B2 ewes on the day after the final injection of progesterone in each series and were removed 1 week later. In the remaining period Group B2 ewes could undoubtedly see and hear rams but contact was not possible.

\section{Detection of oestrus}

Ewes in Groups B and C were observed at 6.00 a.m., 10.00 am., 2.00 p.m., 6.00 p.m. and 10.00 p.m. over the periods of the expected times of oestrus. Observations usually commenced on the afternoon of the day after the final injection of hormone. During this period the ewes were kept in small yards in an open shed (i.e. roof only). Lights were switched on for night observations. Ewes in oestrus were removed into an adjacent yard so that the rams would be encouraged to seek out remaining ewes as they came into oestrus. The time of onset of oestrus was taken as midway between the time the ewe was first detected in oestrus and the previous time of observation. Observations were not continued after Day 6. Ewes in Group A were examined three times per week and ewes showing raddle marks on the rump were recorded as being in oestrus on the day of observation.

\section{Laparotomy}

Laparotomy was carried out on half of the ewes in Group A at intervals of 6 weeks. Thus there was a 12-week period between laparotomies for individual ewes. Laparotomy was conducted by the method outlined by Lamond \& Urquhart (1961). The ovaries were examined for the presence of a recent ovulation or a normal and apparently functional corpus luteum. Where multiple ovulations had occurred, this was recorded also.

\section{RESULTS}

Natural annual rhythm (Group $A$ )

The number of ewes that showed oestrus in the period of 18 days before each laparotomy, and the results of the laparotomy examinations, are shown in. 
Table 1. At each time listed in the table, the oestrus results refer to all ewes, and the ovulation results refer to the half of the ewes in the group that were laparotomized. It is assumed that this sample was representative of the group as a whole. Except in December 1961 and October 1962, there was a higher proportion of ewes showing ovarian cycles (denoted by the presence of a normal corpus luteum) than would be expected from the proportion of ewes observed in oestrus during the period of 18 days before ovarian examination. Even in the period March to July, which is the time of the year when the highest proportion of ewes experience regular oestrous cycles at the Research Station (see Barrett, Reardon \& Lambourne, 1962) approximately $20 \%$ of ewes still had

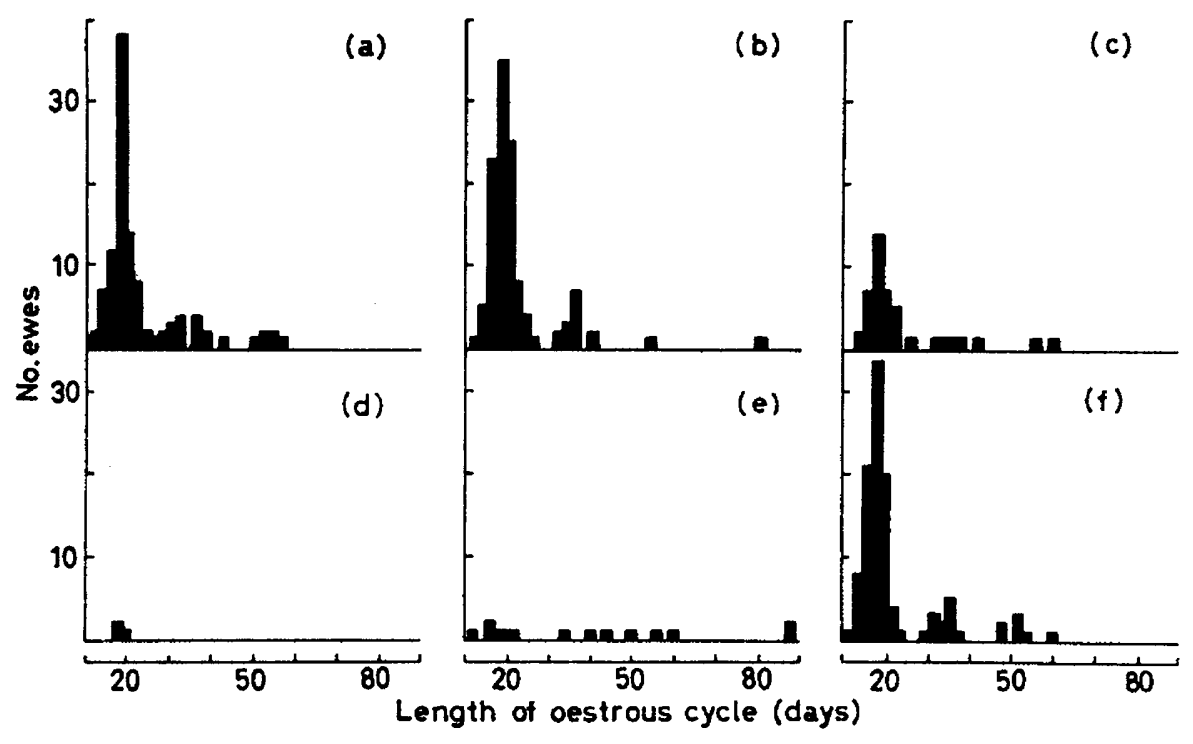

Text-pig. 1. Frequency distribution of oestrus in Group A for successive periods of approximately 60 days between 11 th October 1961 and 6th October 1962. (a) 11th October to 10th December 1961; (b) 11 th December 1961 to 8th February 1962; (c) 9th February to 9th April 1962; (d) 10th April to 8th June 1962; (e) 9th June to 7th August 1962 ; (f) 8th August to 6th October 1962.

normal corpora lutea but were not marked by the ram at the assumed time of ovulation.

As a group, the ewes evidently became anoestrous in November in 1961 and in October in 1962. By mid-January 1962 some ewes had commenced ovarian cycles again and by March all ewes had corpora lutea or recent ovulations.

In Text-fig. 1 are shown the frequency distributions of oestrous cycles in 60-day periods. The peaks of the distribution during the breeding season were such as to indicate that the majority of cycles greater than 19 to 20 days in length, were multiples of 17 to 18 days.

The seasonal pattern seen in Group A differed in one respect from a group of ewes of similar strain and age kept in a small paddock near the yards from August to November 1962. During the second half of October 1962, 30\% of the 
ewes in the paddock showed oestrus; the ovarian picture was not ascertained. The body weights of these ewes were not ascertained but the ewes appeared to be in similar bodily condition to the experimental ewes.

\section{Interval to onset of oestrus after progesterone}

The number of ewes in each group which exhibited oestrus, and the mean period to onset of oestrus and its standard error for the ewes in Group B1 (rams continuously with ewes) are shown in Table 2 . The variation in group size in Group B1 was due mainly to the elimination of ewes that became pregnant, as mentioned above. However, at the end of the experiment one ewe that had never experienced oestrus was found to have hypoplastic ovaries. The records for this ewe were therefore eliminated. Two other ewes died during treatment. Few animals came into oestrus in the week after the final injection in Series 1, 2, 3 and 9. In Series 4, 5 and 6 over $90 \%$ of the ewes exhibited oestrus but, compared with Group A, the incidence of oestrus was less in July and August (Series 7 and 8).

There was a more or less abrupt commencement of oestrus in March and the shortest time to onset of oestrus was generally seen at this time (Series 4). From March to August the increase in the period to onset of oestrus was most marked after progesterone doses of $5 \mathrm{mg} /$ day and $10 \mathrm{mg}$ every 2 days. Over the period March to July (Series 4 to 7 ), there were clear-cut dose-response relationships. Thus after $5 \mathrm{mg} /$ day the period to onset of oestrus was less than after $10 \mathrm{mg} /$ 2 days, which was similar to $10 \mathrm{mg} /$ day, whereas the $20 \mathrm{mg} / 2$ days generally resulted in periods to onset of oestrus of approximately $24 \mathrm{hr}$ longer than $5 \mathrm{mg} /$ day.

In Table 3 are set out the results of Group B2. A proportion of ewes came into oestrus at every series with a maximum during the period March to May (Series 4 to 6). However, unlike Group Bl, a high proportion of ewes showed oestrus in January and July (Series 3 and 7). The overall pattern is similar to Group B1 but an effect on incidence of oestrus due to introduction of rams on Day 1 (which was the day after the final progesterone injection) was apparent in Series 1 to 3 and 7 to 9 . As in Group B1, the period to onset of oestrus was influenced by the progesterone treatments and there was a similar tendency for the shortest periods to occur in the early part of the breeding season (March to April), followed by a consistent increase until anoestrus supervened. The average period to onset of oestrus in Group B2 was not significantly different from Group B1 but dose-response lines were generally flatter, and variances generally smaller, in Group B2.

One of the aims of this experiment was to obtain a quantitative measure of the change in response following progesterone particularly over the period from May to August. The most useful measure of such a change would have been to calculate the degree of displacement of curves relating log dose (progesterone) to response (period to onset of oestrus). However, it is clear that such data are not available for Series 7 and 8 because a number of ewes did not show oestrus. It was decided to compare the total number of ewes exhibiting oestrus in Groups B1 and B2 for Series 7 and 8 (July and August) and to include a comparison with Group A (see Text-fig. 2). An analysis of variance after transformation to 


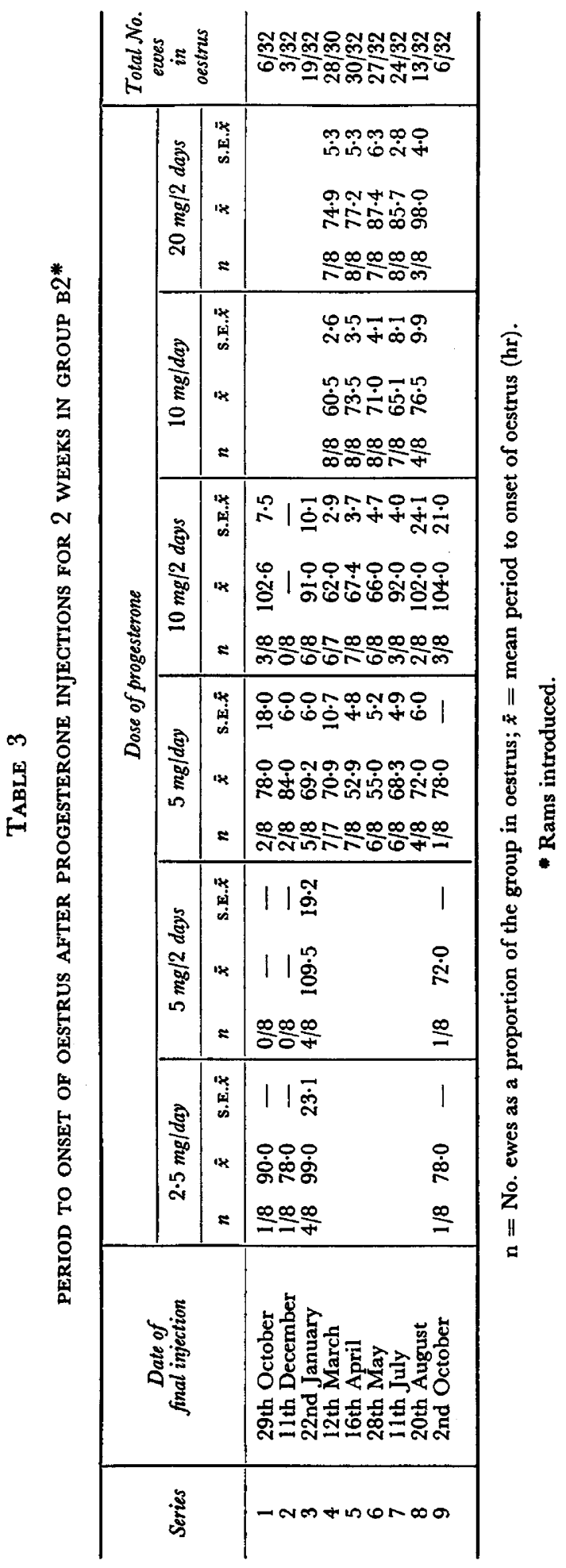


angles disclosed that the three lines are parallel and their positions differ significantly.

The ewes that did not show oestrus after the July progesterone treatments (Series 7) were not more likely to become anoestrous than controls. In Group $\mathrm{B} 1$, four of thirteen ewes that were not in oestrus during the week after the July treatments, also did not return between that time and the August treatments. In Group B2 it was not possible to determine how many ewes did not cycle between Series 7 and 8 but in both Series 8 and 9, where the number of treated ewes showing oestrus decreased, a proportion of such ewes included ones that had not been in oestrus at the previous series. During the period

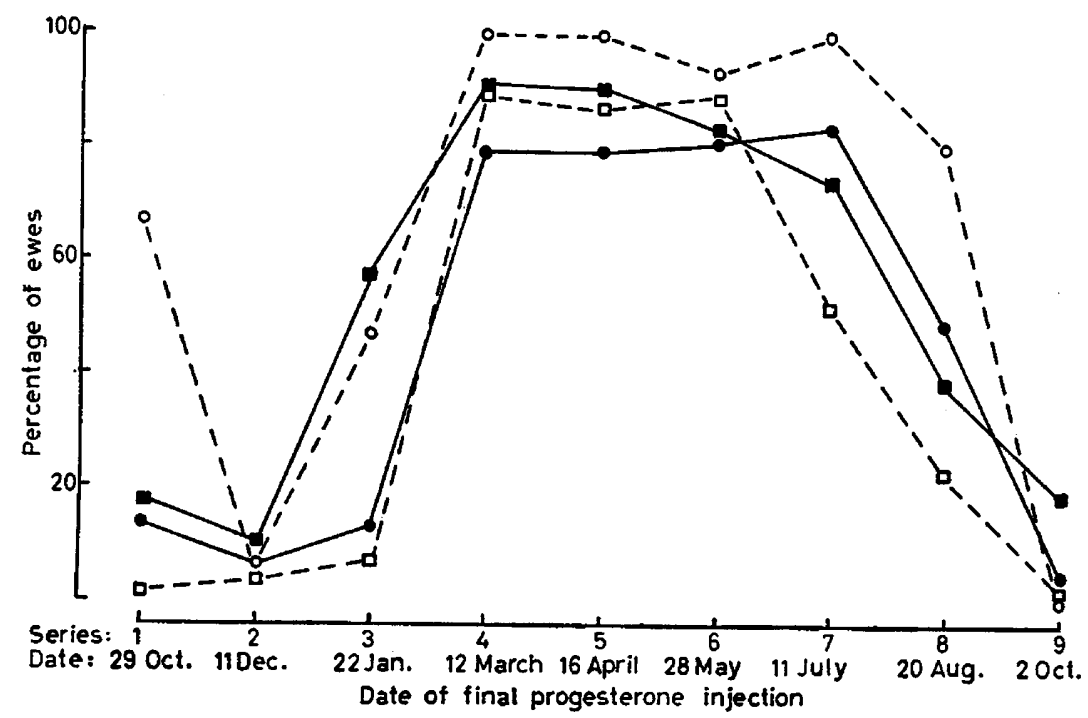

TExT-FIG. 2. Diagrammatic representation of seasonal changes in oestrus and ovulation in normal ewes and ewes treated with progesterone.

, Ewes in Group A showing oestrus in the period of 18 days prior to the date shown (\%).

0 , Ewes in Group A with corpora lutea at the date shown (\%).

$\square$, Ewes in Group B1 (rams continuous) in oestrus in the period of 1 week after cessation of injections of progesterone (\%).

D, Ewes in Group B2 (rams introduced) in oestrus in the period of 1 week after cessation of injections of progesterone (\%).

of 18 days before 11 th July, eight ewes in Group A did not show oestrus and three of these did not exhibit oestrus again throughout the experiment. A further thirteen ewes had entered anoestrus before Series 8 had been completed.

In Series 4, 5 and 6 the proportion of ewes in Groups B1 and B2 that came into oestrus was generally higher than in Group A.

\section{Oestrus in ovariectomized ewes}

The number of ewes in oestrus, and the mean time (and its standard error) of onset of oestrus after the injection of stilboestrol are shown in Table 4. The data respecting one ewe were eliminated when it was discovered at slaughter that she had not been properly ovariectomized. The majority of ewes came into 
oestrus 20 to $30 \mathrm{hr}$ after the injection of oestrogen and the remainder had shown oestrus by $72 \mathrm{hr}$. For purposes of analysis the ewes were given a score for the result of each series as follows: 0 -not in oestrus; 1 -in oestrus 30 to $72 \mathrm{hr}$

TABLE 4

OESTRUS IN OVARIECTOMIZED EWES AFTER PROGESTERONE FOLLOWED BY STILBOESTROL

\begin{tabular}{|c|c|c|c|c|c|c|c|c|c|c|c|c|}
\hline \multirow{3}{*}{ Series } & \multicolumn{6}{|c|}{$2.5 \mathrm{mg}$ progesterone/day } & \multicolumn{6}{|c|}{$10 \mathrm{mg}$ progesterone/day } \\
\hline & \multicolumn{3}{|c|}{$10 \mu \mathrm{g}$ stilboestrol } & \multicolumn{3}{|c|}{40 ug stilboestrol } & \multicolumn{3}{|c|}{$10 \mu \mathrm{g}$ stilboestrol } & \multicolumn{3}{|c|}{$40 \mu \mathrm{g}$ stilboestrol } \\
\hline & $n$ & $\bar{x}$ & S.E. $\bar{x}$ & $n$ & $\bar{x}$ & S.E. $\bar{x}$ & $n$ & $\bar{x}$ & S.E. $\bar{x}$ & $n$ & $\bar{x}$ & s.E. $\bar{x}$ \\
\hline 1 & 1 & - & - & 3 & 25 & 5 & 0 & - & - & 2 & 20 & 0 \\
\hline 2 & 4 & 48 & 11 & $4^{*}$ & 25 & 4 & 3 & 36 & 8 & 5 & 41 & 5 \\
\hline 3 & 0 & & 1 & 7 & 36 & 7 & 2 & 34 & 6 & 4 & 23 & 3 \\
\hline 4 & 3 & 30 & 2 & 6 & 28 & 1 & 1 & - & - & 2 & 29 & 2 \\
\hline 5 & 1 & - & - & 5* & 33 & 5 & 0 & - & - & 1 & $\ldots$ & $=$ \\
\hline 6 & $1 *$ & - & - & 7 & 25 & 4 & 0 & - & - & 6 & 28 & 4 \\
\hline 7 & 3 & 40 & 14 & $2 *$ & 24 & 2 & 0 & - & - & 6 & 40 & 3 \\
\hline 8 & 4 & 45 & 3 & 3 & 42 & 8 & 1 & - & - & 2 & 33 & 7 \\
\hline 9 & 2 & 40 & 0 & 6 & 24 & 1 & 3 & 35 & 11 & 5 & 35 & 5 \\
\hline 10 & 0 & -1 & $\ldots$ & 2 & 35 & 3 & 0 & 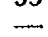 & - & 5 & 30 & 2 \\
\hline
\end{tabular}

$n=$ No. ewes per group in oestrus; $\bar{x}=$ mean period in hours from the injection of oestrogen to onset of oestrus.

- Six ewes per group; otherwise seven per group.

after stilboestrol; 2 -in oestrus within $30 \mathrm{hr}$ of injection. The total treatment group scores are shown graphically in Text-fig. 3. An overall analysis of variance demonstrated significant average differences between series, between doses of

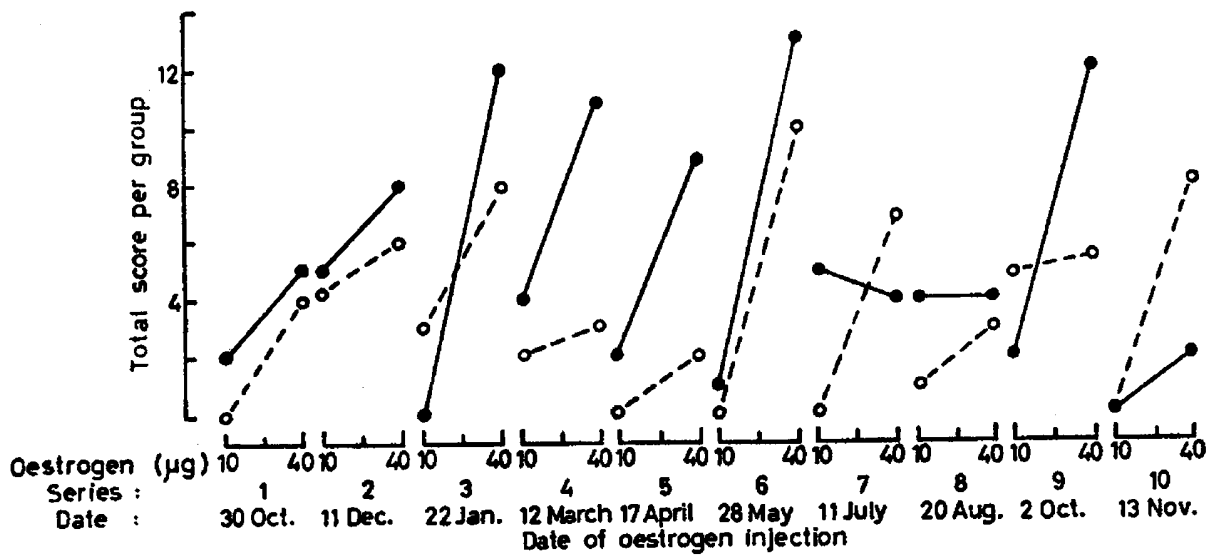

TEXT-FIG. 3. Oestrus in ovariectomized ewes injected with stilboestrol after priming with progesterone $(0,2.5 ; 0,10 \mathrm{mg} /$ day). See text for details of scoring system.

progesterone and doses of oestrogen, but a high proportion of interaction terms were also significant. The general results thus displayed heterogeneity in mean responses and slopes. However, it seemed logical to re-examine the results on 
the basis of the findings in the related groups in this experiment. The period January to May was evidently the time of the year when the sheep were least sensitive to the suppressive action of progesterone. From July to the period of complete anoestrus, ovarian cycles were more easily suppressed by progesterone. It was decided to analyse the January to May results separately (Series 3, 4, 5 and 6).

A summary of the analysis is shown in Table 5 . The stilboestrol doseresponse lines were steeper and more ewes came into oestrus after priming doses of $2.5 \mathrm{mg}$ than after $10 \mathrm{mg}$ of progesterone/day. There were no differences between series and no significant interactions. During the period July to December, there were no differences due to dose of progesterone and the stilboestrol dose-response lines were generally flatter and more variable, particularly after the low priming dose of progesterone. In general the results show considerable time to time variation in response to progesterone and oestrogen. Some of the variation was due to differences between the periods of the year, January to May and July to December, in the number of ewes showing

TABLE 5

SUMMARY OF ANALYSIS OF VARIANCE OF OESTRUS SCORE IN OVARIECTOMIZED EWES IN SERIES 3,4 , 5 AND 6

\begin{tabular}{l|c|c}
\hline \multicolumn{1}{c|}{ Source of variation } & d.f. & Mean square \\
\hline Hormone treatments & & $5 \cdot 14^{* *}$ \\
Dose of progesterone & 1 & $28 \cdot 00^{* *}$ \\
Dose of stilboestrol & 1 & $3.57 *$ \\
Remainder & 1 & 0.80 \\
Series & 3 & 0.83 \\
Interaction & 96 & 0.44 \\
Error & 96 \\
\hline \multicolumn{2}{l|}{} \\
\hline
\end{tabular}

oestrus after a low priming dose of progesterone. It is obvious from Text-fig. 3 that unknown factors also contributed to the overall variability.

\section{DISCUSSION}

It should be emphasized that these results refer to ewes of a particular strain of Merino kept in yards for the duration of the experiment and in a particular climatic environment. The quantitative effect of changes in nutrition was therefore eliminated but it is possible that some form of adaptation took place to the relatively fixed system of management. The differences in ovarian function between October 1961 and October 1962 in the 'control' (Group A) animals and the fact that $30 \%$ of a group of ewes of similar strain, body weight and age in a paddock near the yards were in oestrus in the latter half of October 1962, point to an effect of this kind. Provided, however, there were no interactions between adapted mechanisms and the hormonal or social treatments imposed, comparisons between treatments should not be invalidated. 
'Control' ewes (Group A)

In studies carried out on the same Research Station, Barrett et al. (1962) observed that about $80 \%$ of the possible oestrous periods, on the basis of 17-day cycles in ewes continuously with rams, were detected by the rams. Presumably some ewes did not show oestrus during a period when all ewes might be expected to show oestrus. Similar results were obtained in this experiment, but in addition it has been possible to show that nearly all ewes contained normal corpora lutea during the selected periods of observation. Thus some ewes that should have been in oestrus either did not attract a ram, or refused service. Strictly this phenomenon is 'ovulation without oestrus' or the less accurate though popular 'silent heat'. In January and August, when some ewes gave no indication of ovarian cycles, the number showing oestrus was again less than the number with corpora lutea.

Robinson (1959) indicates that 'silent heat' is likely to occur when an ovulation takes place after a period when the animal has not recently had progesterone priming. This explanation is reasonable for the beginning of the breeding season. To be true later it is necessary to postulate that periods of absence of progesterone secretion occurred but this could only have taken place if apparently normal corpora lutea (on the basis of size, colour and consistency) were in fact abnormal. However, if one assumes that psychic factors associated with the rams influence the effect that progesterone priming has in causing oestrus then it is possible to suggest that 'silent heats' occurred at the beginning of the breeding season because progesterone was absent initially and in the major portion of the breeding season because the rams did not provide sufficient stimulus. The situation during the period August to September is complicated by the fact that the ovarian cycles were more completely suppressed by progesterone.

\section{Effects of progesterone}

The chosen dosage levels of progesterone were evidently greater than the minimal suppressive dose (MSD-the minimum amount of progesterone per day that will suppress ovarian cycles) though the period of 50 to $60 \mathrm{hr}$ to onset of oestrus after $5 \mathrm{mg}$ of progesterone per day in March and April indicates that this dose was close to the MSD. The majority of ewes came into oestrus 2 to 6 days after the final injection of progesterone during the period March to May.

In general, the periods from the final injection of progesterone to the onset of oestrus were similar to those found previously (Lamond \& Lambourne, 1961; Lamond \& Bindon, 1962; Lamond, 1962a). Thus between January and March there occurred a marked increase in number of ewes showing oestrus, even after relatively high dosage levels of progesterone. In the majority of ewes, oestrus was satisfactorily synchronized at each series up to and including May, but by July a significant proportion of ewes did not show oestrus after cessation of progesterone injections. By August, when a high proportion of untreated ewes still showed oestrus regularly, the suppressive effect of progesterone had become most marked as evidenced both by increased periods to onset of oestrus and decreased numbers of ewes showing oestrus.

The central mechanisms responsible for the change in occurrence of oestrus 
after progesterone treatments are unknown though present concepts of hypothalamic control of pituitary function point to the hypothalamus as the area where changes in response to progesterone may occur during the year. Regardless of the mechanism, however, the fact that changes in response of the ewes to the effect of progesterone became pronounced while the untreated ewes were still showing normal oestrus and ovulation, suggests that if production of progesterone by corpora lutea in the period July to August is similar to that in March to June, then cessation of ovarian cycles may be brought about by the increasingly suppressive effect of progesterone from successive corpora lutea, finally inhibiting follicular growth and maturation.

\section{Effect of introduction of the rams}

It is clear that at all times of the year, except the period March to May when the majority of ewes showed oestrus, introduction of the rams on the day after the final injection of progesterone (Group B2) resulted in more ewes showing oestrus than in the group of ewes that received similar progesterone treatments but that had rams with them throughout the year (Group B1). Introduction of rams also affected the characteristic relationship between dose and frequency of progesterone injections and the periods to onset of oestrus seen in Group B1. Variances were generally reduced and slopes were more variable but mean effects did not differ greatly. Discovery of the mechanism of this interaction between the effects on oestrus of progesterone and of the introduction of rams would be a major step forward in understanding the problem of seasonality in reproduction. The stimulus provided by the ram is of considerable significance, since it may invalidate studies where oestrus is a response and the method of detection is incidental to the experiment.

\section{Oestrus in ovariectomized ewes}

During the period January to May, it would appear that $2.5 \mathrm{mg}$ progesterone per day as priming dose led to steeper slopes of the stilboestrol dose-response (oestrus score) lines and the higher average response. At other times $2.5 \mathrm{mg}$ of progesterone was an unsatisfactory priming dose, giving extremely variable results. Results following $10 \mathrm{mg}$ progesterone per day were also variable, showing significant changes in slope. The results may indicate that the optimal combination of progesterone and oestrogen for oestrus in ovariectomized ewes varies with time of year and possibly with other factors, as yet unrecognized.

\section{The concept of the breeding season}

The experiment provides the following new facts for consideration in understanding the concept of a breeding (occurrence of oestrus) and non-breeding (anoestrous) season in the Merino ewe.

1. In ewes kept continuously with rams during the period January to September, there were more ewes containing apparently normal corpora lutea than would be expected on the basis of records of oestrus. This period of ovarian activity extended from approximately 1 month before to 1 month after the breeding season.

2. In January (late summer) the percentage of ewes showing oestrus after 
progesterone was similar to that in the control group, but in July and August fewer ewes showed oestrus after progesterone and the period to the onset of oestrus was greater. A change in response following progesterone treatments occurred before any sign of decline in incidence of natural oestrus.

3. Following comparable progesterone treatments the number of ewes showing oestrus after introduction of rams was greater at the beginning and end of the breeding season than in ewes associated with rams all the time. Hence psychic stimuli associated with rams influenced occurrence of oestrus in ewes treated with progesterone at certain times of the year.

\section{ACKNOWLEDGMENTS}

Mr D. R. Lang and Mr I. Bennett provided valuable skilled assistance at all times.

\section{REFERENCES}

Barrett, J. F., Reardon, T. F. \& Lambourne, L. J. (1962) Seasonal variation in reproductive performance of Merino ewes in northern New South Wales. Aust. F. exp. Agric. Anim. Husb. 2, 69.

DutT, R. H. \& CiAsIDA, L. E. (1948) Alteration of the estrual cycle of sheep by the use of progesterone and its effect on subsequent ovulation and fertility. Endocrinology, 43, 208.

Lamond, D. R. (1962a) Suppression of oestrous cycles in sheep using progesterone. Artificial Breeding of Sheep in Australia, p. 42. Ed. E. Roberts. University of N.S.W. Press.

LAMOND, D. R. (1962b) Anomalies in onset of oestrus after progesterone suppression of oestrous cycles in ewes, associated with introduction of rams. Nature, Lond. 193, 85.

LAMond, D. R. (1963) The effect of nutritive status on oestrus, ovulation and Graafian follicles in Merino ewes. Aust. 7. agric. Res. 14, 483.

LAMOND, D. R. \& Bindon, B. M. (1962) Oestrus, ovulation and fertility following progesterone suppression of ovarian cycles in Merino ewes. F. Reprod. Fertil. 4, 57.

Lamond, D. R. \& Lambourne, L. J. (1961) Suppression of oestrus in sheep with progesterone. Aust. 7 . agric. Res. 12, 154.

Lamond, D. R. \& Urquhart, E. J. (1961) Sheep laparotomy cradle. Aust. vet. 7. 37, 430.

RAdFord, H. M., Watson, R. H. \& Wood, G. F. (1960) A crayon and associated harness for the detection of mating under field conditions. Aust. vet. F. 36, 57.

Raeside, J. I. \& McDonald, M. F. (1959) Seasonal changes in the oestrus response by the ovariectomized ewe to progesterone and oestrogen. Nature, Lond. 184, 458.

Reardon, T. F. \& Robinson, T. J. (1961) Seasonal variations in the reactivity to oestrogen of the ovariectomized ewe. Aust. J. agric. Res. 12, 320.

Robinson, T. J. (1959) The oestrous cycle of the ewe and doe. Reproduction in Domestic Animals, vol. 1. Ed. H. H. Cole \& P. T. Gupps. Academic Press, New York. 